\title{
Tocilizumab in JIA patients who have inadequate response to anti-tumour necrosis factor therapy
}

\author{
R Russo*, M Katsicas \\ From 18th Pediatric Rheumatology European Society (PReS) Congress \\ Bruges, Belgium. 14-18 September 2011
}

\section{Background}

Tocilizumab (TCZ), an IL-6 receptor inhibitor, improves arthritis and systemic symptoms associated with systemic JIA. It may be a valuable option in patients with JIA who show inadequate response to anti-TNF agents.

\section{Aim}

To analyze the short-term effectiveness and safety of TCZ in patients with JIA refractory to anti-TNF agents.

\section{Methods}

All patients who received TCZ due to refractory disease were included. All patients had exhibited anti-TNF primary or secondary failure. Data were retrieved from the Rheumatology Section data base. TCZ was administered intravenously at a dose of $8 \mathrm{mg} / \mathrm{kg}$ for patients $>30 \mathrm{Kg}$, $12 \mathrm{mg} / \mathrm{Kg}$ for patients $<30 \mathrm{Kg}$ every 2 weeks. Efficacy endpoints included improvement (ACR Pedi30), disappearance of systemic symptoms, and reduction in corticosteroid dose.

\section{Results}

9 patients with JIA (7 systemic, 2 poliarticular, 7 F, 2 M) were included. Median age at study entry was 10 years, disease duration 6 years. They received TCZ for 3 to 9 months. Patients had been refractory to etanercept (9), adalimumab (7) or infliximab (2). At baseline (medians): active joints: 11 , joints with limited motion: 4 , wellbeing (0-3): 0.1, disease activity (0-3): 0.45, ESR: $35 \mathrm{~mm} / \mathrm{h}$; CHAQ $>0.53$ patients, fever/rash 1 patient. Six patients were receiving corticosteroids. All patients met improvement criteria, 7 before the 3 rd TCZ infusion. At 1 month after TCZ therapy began: active joints: 4 , joints

\footnotetext{
* Correspondence: rrusso@garrahan.gov.ar Service of Immunology \& Rheumatology, Hospital de Pediatría Prof. Dr. Juan P. Garrahan, Buenos Aires, Argentina
}

with limited motion: 3 , wellbeing: 0.05 , disease activity: 0.24, ESR: $3 \mathrm{~mm} / \mathrm{h}$; CHAQ > 0.51 patient, fever/rash 0 patient. During the treatment, 4 patients reduced dose $(<50 \%)$ of corticosteroids. No side effects were recorded.

\section{Conclusions}

Tocilizumab seems to be effective and safe with a rapid onset of action in children with anti-TNF refractory JIA.

Published: 14 September 2011

doi:10.1186/1546-0096-9-S1-P186

Cite this article as: Russo and Katsicas: Tocilizumab in JIA patients who

have inadequate response to anti-tumour necrosis factor therapy.

Pediatric Rheumatology 2011 9(Suppl 1):P186.
Submit your next manuscript to BioMed Central and take full advantage of:

- Convenient online submission

- Thorough peer review

- No space constraints or color figure charges

- Immediate publication on acceptance

- Inclusion in PubMed, CAS, Scopus and Google Scholar

- Research which is freely available for redistribution

\section{() Biomed Central}

\section{Biomed Central}

